\title{
CORRELATION BETWEEN ASSET IMPAIRMENT AND PROFITABILITY OF SERBIAN LISTED COMPANIES
}

\author{
Vladimir Mitic ${ }^{1 *}$, \\ Tamara Kokic ${ }^{2}$, \\ Vule Mizdrakovic², \\ David Tereladze ${ }^{3}$
}

${ }^{1} \mathrm{PhD}$ candidate,Singidunum University,

Belgrade,Serbia

${ }^{2}$ Singidunum University,

Belgrade,Serbia

3ITMO University, Saint Petersburg, Russia
Correspondence:

Vladimir Mitic

e-mail:

\begin{abstract}
:
The purpose of this paper is to analyse profitability indicators of business entities listed on Belgrade Stock Exchange and correlation with disclosed amount of asset impairment. Namely, entities that have negative financial result or lower financial performance might be motivated to use some of the methods of earnings management. Impairment of a company's assets is sometimes used to manipulate the amount of disclosed result, especially when the observed entity outperforms or under-performs considerably. The research sample includes 400 public companies and their financial statements for 2017 reporting period. The results of this research might be useful for potential investors, as well as other stakeholders, such as financial institutions and tax administration.
\end{abstract}

\section{Keywords:}

financial result, earnings management, financial reports, forensic accounting

\section{INTRODUCTION}

Financial reports are an important instrument of financial reporting designed to provide relevant and reliable information to all interested users. Therefore, it is necessary that they are prepared in accordance with professional and legal regulations. Financial reports have to present financial condition and earnings of an entity in a fair and objective manner. Also, it is important to mention the notion of creative accounting, which is often the subject of scientific research. Creative accounting is the process in which accountants use their knowledge of accounting and financial reporting standards to present financial statements in the best interest of the management (Knežević, Stanišić \& Mizdraković, 2017). However, misconceptions about creative accounting have led to the use of accounting techniques and methods that do not comply with financial reporting regulation. In addition, when interpreting the financial statements, investors carry out more detailed analyses and gather additional information before deciding to invest in an entity (Leković \& Arsenović, 2013). The main victims of creative accounting are certainly owners and investors whose damage is measured by the amount of invested capital that is lost. Apart from owners and investors, creditors are unable to collect their claims when the observed entity has problems with liquidity and therefore suffers damage. Likewise, tax authorities cannot adequately levy taxes, and finally, employees may lose their jobs if an entity goes bankrupt. To conclude, due to the illegal techniques of creative accounting, companies may endanger their reputation on the capital market (Beslić \& Beslić, 2013). Based on the aforementioned, the main research question is defined: Does the amount of assets impairment correlate with 
profitability of Serbian public companies? The structure of the paper is as follows; : the next section provides theoretical background on impairments and explains how they may be linked with legal and illegal earnings management techniques. The second section presents literature review, while research methodology and results are in the focus in the following section. The paper concludes with a summary and directions for future research.

\section{THEORETICAL BACKGROUND}

Depending on the desired financial result, there are numerous techniques which management can use to present financial condition and results of an entity as better or worse. To name a few, the most commonly used creative accounting techniques are: Aggressive accounting, Window dressing, Big bath accounting, Channel stuffing, Cookie jar accounting. The foregoing methods are intended to convey incorrect values of financial report items in order to mislead their users (Jovović, 2015). The most common reasons for management to use manipulative financial reporting techniques are economic motives, such as benefits and bonuses (Simeunović, Grubor, \& Ristić, 2016). The impact of creative accounting is reflected in (Kaparavlović, 2011):

1. Disclosing higher financial results, better earnings capacity and higher value of total assets, and

2. Disclosing lower financial results, loss of earnings capacity and lower value of total assets.

Higher financial result can be disclosed through an overestimation of revenues or an underestimation of expenses. Examples from practice show that revenues are usually more often manipulated than expenses. Revenue manipulation can be in the form of reporting non-existent sales, premature recognition of revenues and overestimation of realized revenues. Expense manipulations can be in the form of capitalization of expenses that should be recognized as an expense in current reporting period. The previously mentioned can be executed by changing accounting policies, underestimating amount of provisions, deferring current expenses to future reporting periods, low write-downs of assets (Cvetković \& Bošković, 2018).

The financial result can be reduced by underestimating revenue or overestimating expenses. The underestimation of revenues can be in the form of delaying the recognition of realized revenues, not recognizing earned revenues, underestimating the value of realized revenues and the like. On the other hand, the overestimation of expenses can be in the form of a non-capital expanditure, overestimation of provisions amount, higher write-offs and recognizing expenses earlier in the current reporting period (Belak, 2011).

\section{IMPAIRMENT OF PROPERTY, PLANT AND EQUIPMENT}

When preparing the financial statements, certain principles and rules that have been defined by International Financial Reporting Standards (IFRS) must be followed. The objective of applying standardized rules and principles is to reflect the comparability of financial reports across countries. However, not all countries have adopted the aforementioned standards which make it difficult sometimes to analyze, interpret and compare the financial statements (Obradović, 2014). Although the goal of implementing international regulation is to improve the quality level of financial reporting, often the regulation leaves room for flexible interpretation by the accountant and management of an entity. In addition to IFRS $15-$ Revenue from Contracts with Customers (previously International Accounting Standard 18 - Revenue), which is often misused in recognizing revenues, a commonly used standard when manipulating earnings is IAS 36 - Impairment of Assets. The mentioned standard is one of the most complex standards/ones, because it implies that it is mandatory to perform valuation of the assets, an activity usually too complex for accountants. For this purposes, certified independent valuers are usually hired, as the process of assets valuation requires unique skill sets and experience.

The objective of introducing IAS 36 is to define procedures that will not result in an asset being valued at a value higher than recoverable amount. That amount is the higher amount of: fair value less the estimated cost of disposal or value in, whichever is higher. If, at/on the balance sheet date or at any time when impairment test is performed, the net book value of an asset (purchase cost less accumulated depreciation and accumulated impairments) exceeds its recoverable amount, it is necessary to impair the asset. If this occurs, the net book value must be reduced to recoverable amount and the difference arising is recognized as an Impairment loss in Income statement or as a decrease of Revaluation surplus in the Balance Sheet when the revaluation model is used (Jeftić-Arsenović, 2016). At the end of each year, management must make an assessment of all entity's assets and consider whether there are indicators showing that assets in the Balance sheet are disclosed at a value exceeding the recoverable amount. Testing fixed assets for impairment is an obligation of all business entities prior to the preparation of the financial statements. Namely, fixed assets usually represent the majority of an entity's assets and when they are not impaired, the financial reports do not present an objective and fair condition of entity. Therefore, it is necessary to test the assets for impairment in order to determine their current value and to present the results of the impairment in the Notes to the financial statements (Manojlović, 2016). 
Impairment test is carried out at least once a year or more frequently if there is an indication that the carrying amount of the asset is significantly different from the recoverable amount (Milojević \& Terzić, 2013).

When testing assets impairment, management may subjectively make an assessment. It is doubtful whether the losses incurred or reversed are objectively estimated or represent the managers' efforts to present favorable or less favorable financial condition of an entity. In contrast, without any doubt, impairment of property, plant and equipment affects financial condition and profitability of an entity. More specifically, high amounts of property impairment have the effect of reducing the value of assets, as shown in the Balance Sheet. At the same time, high impairment losses will increase expenses recognized in Income statement, which decreases net result. If overestimated write-off is made, hidden reserves will appear because assets are underestimated. Therefore, higher next results could be expected in the future. As a reward for better performance, managers might receive higher salaries and bonuses. When the management of an entity needs to attract investors or gather more financial assets easily, it might impair the assets in minimal amounts so that the book value of the assets appears higher than it actually is. As a consequence, investors' interest in the company's shares will increase and the management will have easier access to additional investment, better credit rating and lower interest rates (Skarić \& Jovanović, 2007).

\section{LITERATURE REVIEW}

The author Chunguang (2006), conducted a study that observed the correlation between assets impairment and earnings management. The research found that poorly performing companies use impairment of assets to show better financial results, or to show lower operating losses. In contrast, companies that have a good financial result and operate profitably use asset impairments to reduce their business results and pay lower corporate income taxes. In the research conducted by Lhaopadchan (2010), it has been concluded that managers are often motivated to manage revenues and to use goodwill impairment for this purpose. It has also been noted that investors and analysts are cautious when interpreting the financial reports and make more detailed analyzes of a company in order to make business decisions. The results of the research conducted by Xu, Anandarajan \& Curatola (2011) show that investors observe the impairment of assets in negative context, as they consider it to be a company's weakness and possible liabilities reconstruction.

One of the problems with the implementation of IAS 36 - Impairment of Assets was pointed out in the research by Kuzmina and Kozlovska (2012). The authors conduct- ed a survey at a Lithuanian company whose primary business is fuel retail and concluded that accountants were sometimes not competent enough to estimate assets impairment. The authors believed that accountants needed the assistance of a financial analyst or certified valuer in order to complete the estimation of impairment. Management was often interested in presenting results better than they actually were in order to earn bonuses.

Research conducted by Laskaridou, et al. (2014), included a sample of 236 public companies. The survey found that management in companies that disclosed impairment had lower salaries than management in companies that did not use property impairment. It was also stated that the management in these companies had recorded high amounts of asset impairment in order to apply the big bath accounting technique and receive higher salaries and bonuses in the future. A similar survey was conducted by Abuaddous, et al. (2014) and the results showed that managers in Malaysia most commonly use goodwill in the big bath accounting technique. Goodwill is well suited to manipulating earnings, as confirmed in the research by Jahmani, Dowling \& Torres (2010). The sample includes companies that disclosed goodwill in the Balance Sheet in the period 2003-2005. Researchers have come to the conclusion that goodwill is not amortized but that impairment tests are performed. Namely, the amounts of goodwill impairment do not have to be the same over several reporting periods, so this allows flexibility for management to choose the moment when they will impair goodwill and thus affect the business result.

Finally, authors Fernandes, et al. (2016), conducted a survey on a sample of 80 Spanish and Portuguese companies in the period 2007-2011 whose shares were listed on the stock exchange. The results of the research showed that assets impairment was mostly related to intangible assets, primarily goodwill. The survey found that Portuguese export-oriented companies did not recognize impairment losses, while companies with high market values were more likely to recognize those losses. A comparison of Spanish and Portuguese companies showed that Spanish companies recorded higher amounts of impairments in comparison to Portuguese companies.

\section{RESEARCH METHODOLOGY AND RESULTS}

In order to provide an answer to defined research question a research has been conducted. The research sample included 400 companies from Serbian stock exchange and their financial reports for 2017 reporting period. The reports were collected from the official site of Serbian Business Registers Agency. Afterwards, the main financial ratios that measure profitability have been calculated: Gross and Net margin, Return on assets (ROA), 
Earnings before interest and taxes (EBIT), Earnings before interest, taxes, depreciation and amortization (EBITDA), Retained earnings to total assets, Sales revenues to total assets and Loss above capital (LOSS). Person correlation coefficients for observed variables are presented in the table that follows. The observed variable Impairment of assets includes all financial report items that refer to impair- ment. The amount is calculated as the sum of following income statement items: 583 - Impairment of Long-term Financial Instruments and other Securities Available for Sale; 585- Impairment of Receivables and Short-term Financial Instruments, 57 - Other Expenses; 58 - Expenses from Value Adjustment of Other Assets Disclosed at Fair Value through Income Statement.

Table1- Pearson correlation coefficient for observed variables

\begin{tabular}{|c|c|c|c|c|c|c|c|c|}
\hline Variables & $\begin{array}{l}\text { Gross } \\
\text { margin }\end{array}$ & Net margin & ROA & EBIT & EBITDA & $\begin{array}{l}\text { Retained } \\
\text { earnings to } \\
\text { total assets }\end{array}$ & $\begin{array}{c}\text { Sales } \\
\text { revenues to } \\
\text { total assets }\end{array}$ & LOSS \\
\hline \multirow{2}{*}{ Asset impairment } & .014 & -.050 & $.129^{*}$ & $.148^{\star *}$ & $.125^{\star}$ & .050 & .085 & .046 \\
\hline & .784 & .333 & .010 & .003 & .012 & .322 & .092 & .364 \\
\hline \multirow{2}{*}{ Gross margin } & & $-.667^{\star *}$ & $.454^{* *}$ & .010 & .008 & -.069 & .064 & $-.194^{\star *}$ \\
\hline & & .000 & .000 & .847 & .878 & .180 & .214 & .000 \\
\hline \multirow{2}{*}{ Net margin } & & & $-.293^{\star *}$ & .000 & .001 & .087 & -.001 & .034 \\
\hline & & & .000 & .995 & .982 & .091 & .992 & .501 \\
\hline \multirow{2}{*}{$\mathrm{ROA}$} & & & & .047 & .039 & $-.388^{\star *}$ & $.136^{* *}$ & $-.229 * *$ \\
\hline & & & & .348 & .437 & .000 & .007 & .000 \\
\hline \multirow{2}{*}{ EBIT } & & & & & $.990^{\star *}$ & .045 & .003 & -.050 \\
\hline & & & & & .000 & .373 & .948 & .315 \\
\hline \multirow{2}{*}{ EBITDA } & & & & & & .042 & .005 & -.040 \\
\hline & & & & & & .409 & .928 & .430 \\
\hline \multirow{2}{*}{$\begin{array}{c}\text { Retained earnings to } \\
\text { total assets }\end{array}$} & & & & & & & .024 & .093 \\
\hline & & & & & & & .633 & .063 \\
\hline \multirow{2}{*}{$\begin{array}{l}\text { Sales revenues to } \\
\text { total assets }\end{array}$} & & & & & & & & $-.144^{* *}$ \\
\hline & & & & & & & & .004 \\
\hline
\end{tabular}

Results show that there is a statistically significant correlation between the observed variable Asset impairment and EBIT, ROA and EBITDA. These variables are positively correlated, which means that profitable entities have higher value of asset impairment.Namely, profitable entities usually report very high net result, which is taxable. Therefore, they are motivated to use creative accounting techniques to decrease reported result, as explained previously. All other variables have positive correlation with Asset impairment except for Net margin. Therefore, it can be concluded that companies with lower reported Net result have higher value of asset impairment.The aforementioned is the proof of the use of earnings management techniques, because impairments decrease the value of Net result. Finally, the results show that business entities that reported loss above capital have higher impairments. Those entities usually have very high probability of opening bankruptcy proceedings. Namely, their assets are usually very close to the end of their useful life and impairments occur more often due to insufficient maintenance and technological improvements.

\section{CONCLUSION AND DISCUSSION}

This paper is related to the use of creative accounting techniques and their influence on the quality of financial reporting by analyzing the correlation between asset impairment and profitability. Namely, the research paper examines the effects of asset impairment on the revenue generated and the profitability of public companies listed on the Belgrade Stock Exchange. If the financial statements are not prepared according to the professional and legal regulations, users of the financial statements might be mislead in business decision making process. The research confirmed that profitable companies that achieve high net results tend to use creative accounting techniques to reduce the amount of taxable profit. Also, the correlation results show that companies with lower amounts of net results show high amounts of impairment. The above mentioned manipulative techniques affect the reputation of companies in the public. Namely, creative accounting caused many users of financial reports to lose their confidence in the objectivity and truthfulness of financial reports, which is why many investors may delay the decision to invest in a company or withdraw their investment (Adeyemi, Omobude, \& Udofia, 2019). Nowadays, 
creative accounting techniques are widely represented and used by the management of numerous companies. In this regard, their usage cannot be eliminated. More specifically, companies must retain the flexibility to apply and define accounting policies. However, this flexibility is conditional on compliance with the code of ethics and regulatory requirements. Considering that the application of the previous leads to relevant information in the financial statements, that may be useful for stakeholders, financial institutions and tax administration. For future research it can be recommended to analyze specific types of asset impairments, e.g. goodwill, other intangible assets, account receivables; and their correlation with profitability indicators.

\section{LITERATURE}

1. Abuaddous, M., Hanefah, M. M.; Lail, N. H. (2014). Accounting Standards, Goodwill Impairment and Earnings. International Journal of Economics and Finance, VI(12), 201-211. DOI:10.5539/ijef.v6n12p201

2. Adeyemi, S. B., Omobude, S. I., \& Udofia, I. E. (2019). Impairment Testing of Intangible Assets and Quality of Financial Reporting of Nigerian Manufacturing Companies. Global Journal of Accounting.

3. Belak, V. (2011). Poslovna forenzika i forenzično računovodstvo. Zagreb: Belak Excellens.

4. Beslić, D.; Beslić, I.(2013). Stečaj privrednog društva kao posledica manipulativnog finansijskog izveštavanja. Škola biznisa, 148-159. DOI:10.5937/skolbiz1304148B

5. Chunguang, Z. (2006). Asset Impairments and Earnings Management. Accounting Research, 11-17. Retrieved from http://en.cnki.com.cn/Article_en/CJFDTOTALKJYJ200603003.htm

6. Cvetković, D., Bošković, V.(2018). Pojavni oblici kreativnog računovodstva i najčešće manipulacije u finansijskim izveštajima. Oditor - časopis za Menadžment, finansije i pravo, IV(2), 78-89. Retrieved from https:// scindeks.ceon.rs/article.aspx?query=ISSID $\% 26$ and $\% 26$ 13973 \&page $=7 \&$ sort $=8$ \&stype $=0$ \&backurl=\%2Fissue . aspx\%3Fissue \%3D13973

7. Fernandes, J. S., Gonçalves, C., Guerreiro, C., \& Pereira, L. N. (2016). Impairment losses: causes and impacts. $R B G N$ Review of Business ManagementT, XVIII(60), 305-318. DOI: 10.7819/rbgn.v18i60.2300

8. Jahmani, Y.,Dowling, W. A., Torres, P. D. (2010). Goodwill Impairment: A New Window For Earnings Management? The Journal of Business \& Economics Research (JBER) , VIII(2), 19-24.DOI: https://doi.org/10.19030/ jber.v8i2.669

9. Jeftić-Arsenović, V. (2016). Specifičnosti obezvređenja i prestanka priznavanja nekretnina, postrojenja i opreme. Naučno-stručni časopis SVAROG, XII, 171-182. DOI: 10.7251/SVR1612171A
10. Jovović, M. (2015). Kreativno računovodstvo - teorijski i praktični aspekti. Economics \& Economy, II(5), 73-85. Retrieved from http://www.economicsandeconomy.me/sites/economicsandeconomy.me/files/jovovic.pdf

11. Kaparavlović, N. (2011). Uticaj kreativnog računovodstva na kvalitetet finansijskog izveštavanja. Ekonomski horizonti, XIII, 155-168. Retrieved from http://www.horizonti.ekfak.kg.ac.rs/sites/default/files/Casopis/2011_1/9_Nemanja_Karapavlovic.pdf

12. Knežević, G., Stanišić, N., Mizdraković, V. (2017). Analiza finansijskih izveštaja. Beograd: Univerzitet Singidunum. Retrieved from https://singipedia.singidunum. ac.rs/izdanje/42555-analiza-finansijskih-izvestaja-drugoizmenjeno-i-dopunjeno-izdanje

13. Kuzmina, I., Kozlovska, I. (2012). Accounting Measurement of Long-Lived Assets: A Case of Impairment Practice. Journal of Business Management, (5), 56-65. Retrieved from https:/www.researchgate.net/ profile/Dimitrios_Maditinos/publication/287646255_ Firm_Performance_Corporate_Decision_and_ the_Role_of_Managerial_Optimism_The_Case_ of_Greece_Literature_Review_and_Methodology/ links/5678648508ae502c99d56d2c/Firm-Performance Cor

14. Laskaridou, E. C., Athanasios, E., Stergios, A. (2014). Detecting Asset Impairment Earnings Management on IFRS Context: Some Evidence from Greek Listed Companies. American Journal of Applied Sciences, XI(6), 963-968. DOI : 10.3844/ajassp.2014.963.968

15. Leković, M., Arsenović, S. (2013). Uloga i značaj kvalitetnog finansijskog izveštavanja. Bankarstvo, XLII(4), 78-95. Retrieved from http://www.ubs-asb.com/Portals/0/Casopis/2013/4/UBS-Bankarstvo-4-2013-Leković-Arsenović.pdf

16. Lhaopadchan, S. (2010). Fair value accounting and intangible assets. Journal of Financial Regulation and Compliance, XVIII(2), 120-130. DOI:https://doi. org/10.1108/13581981011033989

17. Manojlović, B. (2016). Non-Current Assets Impairment Testing. Auditor, XIX(75), 33-43. Retrieved from http:// revizor.ief.rs/index.php/revizor/article/view/88

18. Milojević, M., Terzić, I. (2013). Impact of Interna-tional Regulatiory Framework of Financial Reporting Company Taken from the Aspect of Fixed Assets. 14. Međunarodni naučni skup Sinergija 2013 (pp. 176-183). Bijeljina: Univerzitet Sinergija. Retrieved from https:// www.researchgate.net/profile/Predrag_Vukadinovic/publication/304035144_Globalizacija_I_ Strane_Direktne_Investicije_U_Srbiji-Globalization_And_Foreign_Direct_Investment_In_Serbia/ Links/5763f84108aeb4b997fc8b1e/Globalizacija-I-StraneDirektne-Invest

19. Obradović, V. (2014, December). Nekonzistentna primena međunarodnih standarda finansijskog izveštavanja. Ekonomski horizonti, XVI(3), 239 - 251 . DOI: 10.5937/ekonhor1403239O 
20. Simeunović, N., Grubor, G., \& Ristić, N. (2016). Forensic Accounting in the Fraud Auditing Case. European Journal of Applied Economics, 45-56.

21. Skarić-Jovanović, K. (2007). Kreativno računovodstvo motivi, instrumenti i posledice. Zbornik radova: Mjesto $i$ uloga računovodstva, revizije i finansija u novom korporativnom okruženju, 51-70. Retrieved from http://www. ekof.bg.ac.rs/wp-content/uploads/2014/05/kreativnoracunovodstvo.pdf

22. Xu, W., Anandarajan, A., Curatola, A. (2011, October). The value relevance of goodwill impairment. Research in Accounting Regulation, XXIII(2), 145-148. doi:https://doi. org/10.1016/j.racreg.2011.06.007 